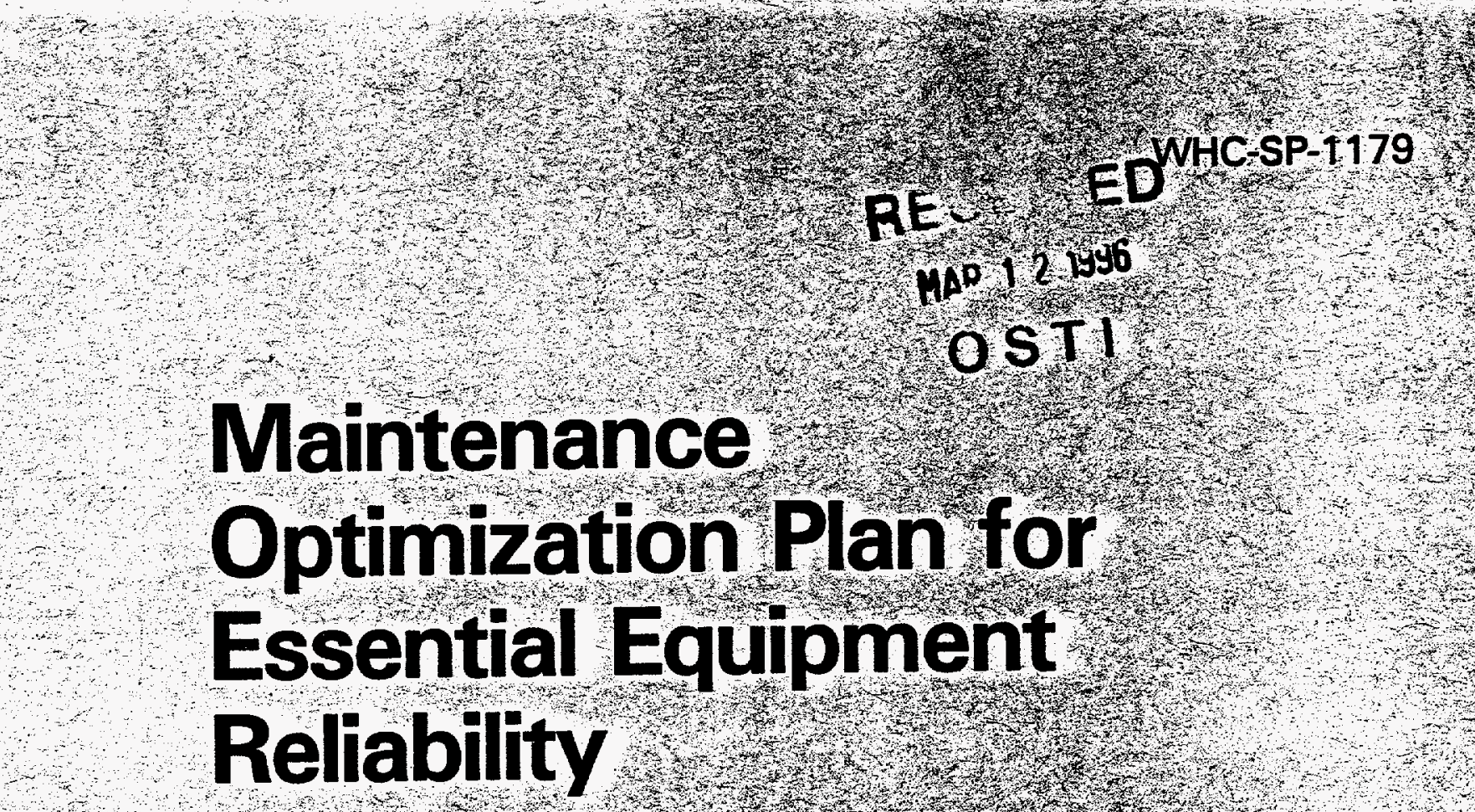

Prepared for the U.S. Department of Energy Assistant Secretary for Environmental Management

Westinghouse
Hanford Company Richland, Washington

Management and Operations Contractor for the

U.S. Department of Energy under Contract DE-AC06-87RL10930

Approved for public release; distribution is unlimited 
LECAL DECLAMER

This report was prepered as an account of work sponsored by an eqency of the United States Govemment. Neither the United States Government nor any agoncy thereof, nor eny of their employeses, nor any of their contrectors, subcontrectors or their employees, makes any warranty, oxpress of in pitiod, or assumes any logal liability or responsibifity for the accuracy, completenoss, of any third party's use of the results of auch use of any information, apperatus, product, or process disclosed, or represents that its use would not infringe privately owned riohts. Reforence horein to any specific commorcies product, process, or senvice by trede neme, trademenk, manufacturer, or otherwise, does not nocesestity constitute or imply its endorsement, recommendetion, of fevoring by the United States Govornment of eny agoncy thereof or its contractors or subcontractors. The viows and opinions of authors oxpresed herein do not necesserily otete or reflect thoes of the United States Government of ary egency thereof.

This roport hes boen reproduced from tho best aveliblo copy. Aveilable in peper copy and microficho.

Aveilable to the U.S. Department of Energy. and its contractors from

U.S. Depertment of Energy

Office of Scientific and Technical Information (OSTI)

P.0. Box 62

Oek Ridge, TN 37831

(615) 576-8401

Pinted in the Unitod States of Ameice

DISCLM-3.CHP (1-91) 


\section{Maintenance Optimization Plan for Essential Equipment Reliability}

D. H. Steffen

Date Published

February 1996

Prepared for the U.S. Department of Energy

Assistant Secretary for Environmental Management

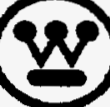

Westinghouse

P.O Box 1970

Hanford Company Richland, Washington

Management and Operations Contractor for the

U.S. Department of Energy under Contract DE-AC06-87RL10930

Approved for public release; distribution is unlimited 


\section{RELEASE AUTHORIZATION}

Document Number: WHC-SP-1179

Document Title: Maintenance Optimization Plan for Essential Equipment Reliability

Release Date: $\quad 2 / 22 / 96$

This document was reviewed following the procedures described in WHC-CM-3-4 and is:

APPROVED FOR PUBLIC RELEASE

WHC Information Release Administration Specialist:

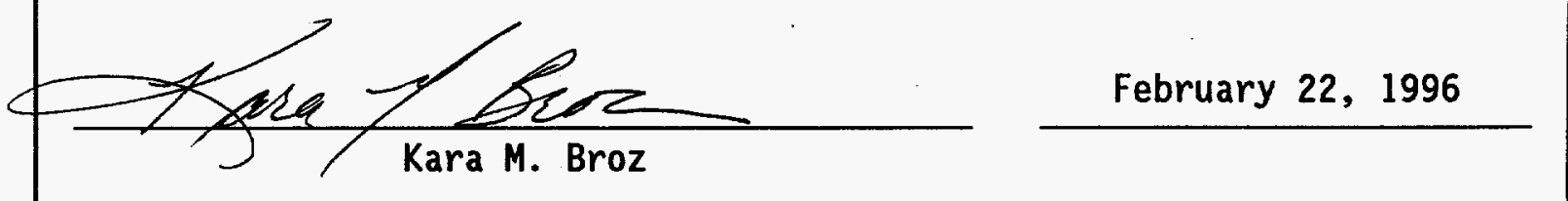




\section{DISCLAMMER}

Portions of this document may be illegible in electronic image products. Images are produced from the best available original document. 


\section{CONTENTS}

1.0 EXECUTIVE SUMMARY $\ldots \ldots \ldots \ldots \ldots \ldots \ldots \ldots \ldots \ldots \ldots$

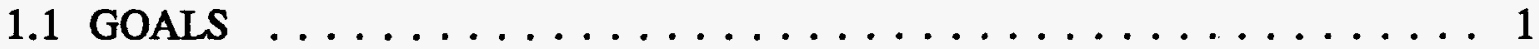

1.2 MOP MISSION . . . . . . . . . . . . . . . . 1

1.3 MAINTENANCE OPTIMIZATION PROGRAM COMPONENTS . . . . . 1

2.0 MAINTENANCE OPTIMIZATION PLAN STRATEGY SUMMARY $\ldots \ldots \ldots \ldots 2$

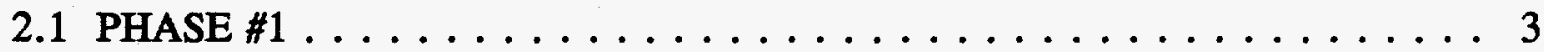

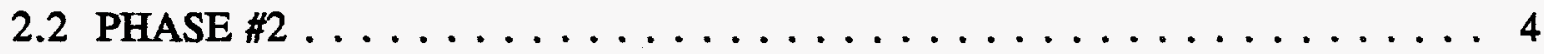

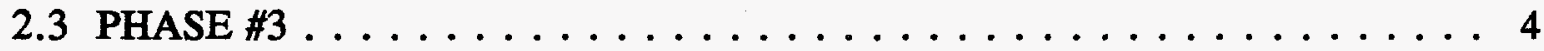

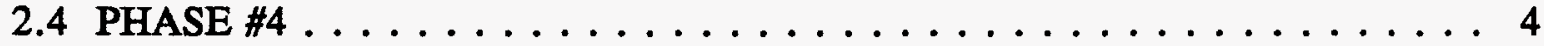

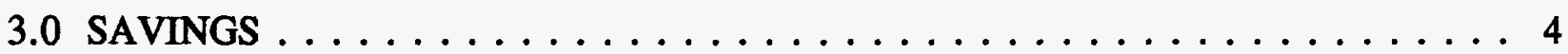

4.0 PLAN FOR SSC REVIEW $\ldots \ldots \ldots \ldots \ldots \ldots \ldots \ldots \ldots \ldots$

5.0 MAINTENANCE DEFINITIONS $\ldots \ldots \ldots \ldots \ldots \ldots \ldots \ldots \ldots$

5.1 CORRECTIVE MAINTENANCE $\ldots \ldots \ldots \ldots \ldots \ldots \ldots$

5.2 ESSENTIAL STRUCTURES, SYSTEMS AND COMPONENTS $\ldots \ldots \ldots 5$

5.3 EQUIPMENT CONDITION MONITORING PROGRAM . . . . . . . . 5

5.4 LINE MANAGEMENT $\ldots \ldots \ldots \ldots \ldots \ldots \ldots \ldots \ldots$

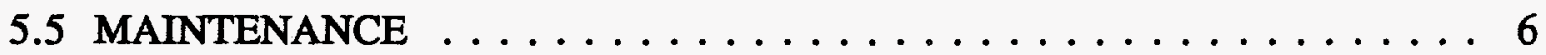

5.6 PLANNED MAINTENANCE $\ldots \ldots \ldots \ldots \ldots \ldots \ldots \ldots \ldots \ldots$

5.7 PREDICTIVE MAINTENANCE $\ldots \ldots \ldots \ldots \ldots \ldots \ldots \ldots$

5.8 PREVENTIVE MAINTENANCE $\ldots \ldots \ldots \ldots \ldots \ldots \ldots \ldots$

5.9 RELIABILITY-CENTERED MAINTENANCE $\ldots \ldots \ldots \ldots \ldots \ldots$ 


\section{LIST OF TERMS}

ALARA

ESSC

MOP

RCM

SSC

TWRS as low as reasonably achievable essential structures, systems, and components Maintenance Optimization Plan reliability-centered maintenance structures, systems and components

Tank Waste Remediation Systems 


\section{MAINTENANCE OPTIMIZATION PLAN FOR ESSENTIAL EQUIPMENT RELIABILITY}

\subsection{EXECUTIVE SUMMARY}

The Maintenance Optimization Plan (MOP) for Essential Equipment Reliability will furnish Tank Waste Remediation System (TWRS) management with a pro-active, forward-thinking process for maintaining essential structures, systems, and components (ESSC) at the Hanford Site tank farms in their designed condition, and to ensure optimum ESSC availability and reliability.

\subsection{GOALS}

The MOP has four goals:

1. Increase ESSC reliability

2. Provide positive configuration control during maintenance activities

3. Establish a long-term Equipment Condition Monitoring Program.

4. Reduce maintenance cost.

\subsection{MOP MISSION}

The mission of the MOP is to provide an effective equipment reliability program, based on an analysis of failure modes, failure rates, and the primary characteristics of the ESSC, for safe operation of the facility.

\subsection{MAINTENANCE OPTIMIZATION PROGRAM COMPONENTS}

To maintain ESSC in their designed condition, and ensure their optimum availability and reliability, the following items will be addressed by the core team (see Section 2.0):

- Facility structures, systems and components (SSC) will be identified in essential and non-essential categories

- Failure modes will be analyzed to determine program adjustments

- Procedure and instructional adjustments will be made as appropriate

- Recommendations will be made to enhance management control

- A monitoring system will be established as a feedback mechanism. 


\subsection{MAINTENANCE OPTIMIZATION PLAN STRATEGY SUMMARY}

The MOP strategy is a four-phase process used to develop an essential equipment reliability program. These phases are as follows:

1. Identification and analysis of ESSC for equipment failure modes and rates

2. Development of an equipment reliability program

3. Implementation of the equipment reliability program

4. Incorporation of an equipment condition monitoring program.

An overview of the MOP is illustrated below. Each of the phases is further explained in subsequent sections.

\section{TWRS MANIENANCE OPTIMIZATION PLAN - SUMMARY}

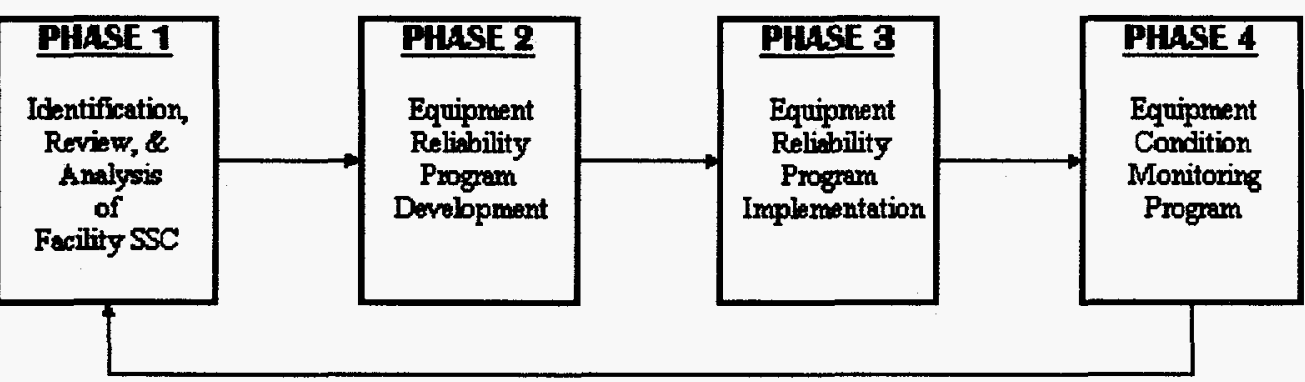

Ongoing Feedback Process

Ensential Fqui pmeat

1 Equipmont important to safety \& emrizonmental operations.

2.Equipment important to the relisbility of the prochuction process.

\begin{tabular}{|c|c|}
\hline PHASE 1 & 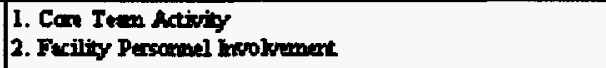 \\
\hline PHASE 2 & 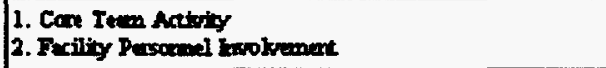 \\
\hline PHASE $\mathbf{3}$ & 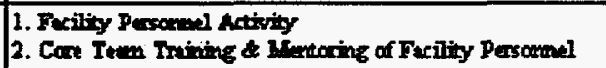 \\
\hline PHI & 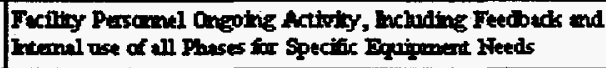 \\
\hline
\end{tabular}

1 
The MOP strategy is to have a focused, dedicated team working closely with each organization to produce a consistent quality product that will be integrated into the existing process. Two teams are needed to implement the MOP. The first team is a core team that performs the analysis, and develops and implements the equipment reliability program. The second team is the facility's normal management organization. This team implements the reliability program and maintains the equipment condition monitoring program.

\subsection{PHASE \#1 - IDENTIFICATION, REVIEW AND ANALYSIS OF FACILITY SSC}

To reduce operational impacts, the involvement of facility personnel is limited. An overview of Phase \#1 is illustrated below. The core team will establish a database of all ESSC to be included in the scope of the MOP; this database will be developed as a result of a review of facility SSC.

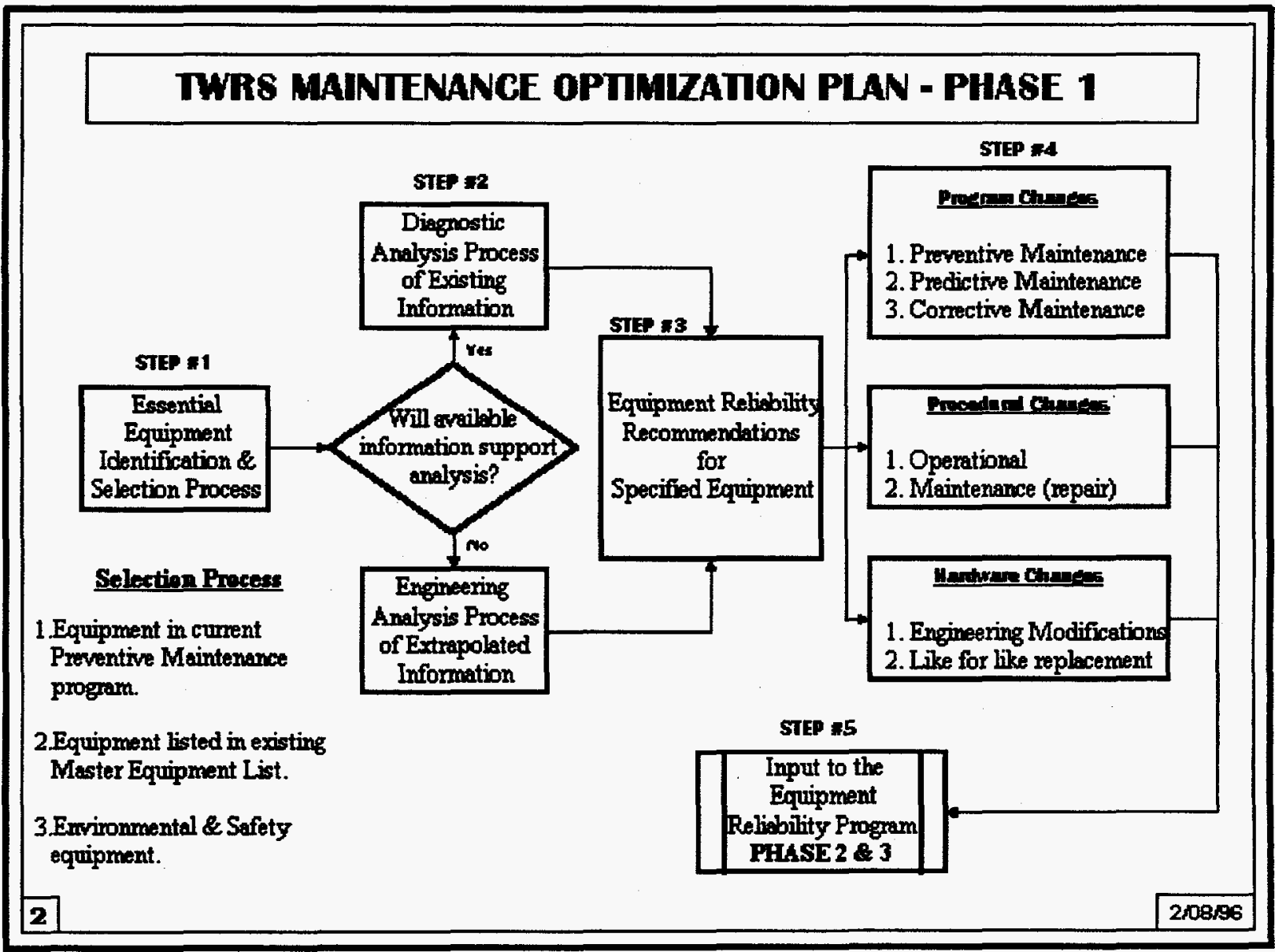




\subsection{PHASE \#2 - EQUIPMENT RELIABILITY PROGRAM DEVELOPMENT}

Phase 2 is also performed by the core team. In this phase all ESSC will be identified in a maintenance plan. Specific maintenance tasks (i.e., corrective, preventive, or predictive) will be identified and new work documentation developed as necessary.

\subsection{PHASE \#3 - EQUIPMENT RELIABILITY PROGRAM IMPLEMENTATION}

Phase 3 is intended to integrate the essential equipment reliability program into the current maintenance organization. The involvement of facility personnel is essential. The core team will train and mentor the facility personnel during this phase.

\subsection{PHASE \#4 - EQUIPMENT CONDITION MONITORING PROGRAM}

Phase 4 is implementation of the essential equipment monitoring program. Facility personnel ownership of the process is imperative. This phase includes monitoring, analysis (if required), and recommendations for program changes. Proposals can be directed to initiate repair, change the maintenance plan, develop and install modifications, or supply like-for-like replacements.

\subsection{SAVINGS}

Reducing maintenance cost is one of the goals of the MOP. The typical cost saving experienced in other industrial facilities that have used reliability-centered maintenance (RCM) techniques (see Section 5.9) to optimize their maintenance is a $20 \%$ reduction in preventive maintenance actions and a $10 \%$ reduction in corrective maintenance. This level of return is not expected in the first year, but should produce significant improvement in equipment operability and reduced cost in the second, third, and out years. In the third and subsequent years this would equate to an annual savings of about $\$ 800,000$ from preventive maintenance, and about $\$ 1,500,000$ in corrective maintenance. These reductions are based on current costs related to maintenance activities supporting tank farms transition projects. 


\subsection{PLAN FOR SSC REVIEW}

The SSC review plan is as follows:

- Review the SSC for double-shell tanks (241-AN will be used as the model)

- Review the SSC for controlled, cleaned, and stabilized single-shell tanks (241-TY will be used as the model)

- Review the SSC for the 242-A evaporator

- Review the SSC for the remaining single-shell, double contained receiver tanks and SSC for other facilities as required.

\subsection{MAINTENANCE DEFINITIONS}

\subsection{CORRECTIVE MAINTENANCE}

Corrective maintenance is the repair and restoration of equipment or components that have failed, are malfunctioning, or are not performing their intended function. Corrective maintenance activities should ensure that the condition that caused the failure is identified, corrected, and documented. Analysis should be performed to determine the root-cause or causes of failure, and appropriate corrective actions should be taken. Those actions could include feedback into the preventive and predictive maintenance programs.

\subsection{ESSENTIAL STRUCTURES, SYSTEMS AND COMPONENTS}

Essential structures, systems and components (ESSC) are those classifications of SSC that are important to safety and the environment and to the reliability of plant operations.

\subsection{EQUIPMENT CONDITION MONITORING PROGRAM}

The Equipment Condition Monitoring Program monitors the performance or condition of ESSC against established operational parameters to provide assurance that ESSC are capable of fulfilling their intended function. These parameters should be established taking into account safety and industry-wide operating experience. Systems configuration and operating parameters will be established to ensure proper monitoring conditions for in-process monitoring and to help ensure the data collected are comparable and trendable. ESSC 
monitoring locations should be identified and marked so that consistent readings can be obtained, and knowledgeable individuals must review and analyze this data to predict and address failures.

\subsection{LINE MANAGEMENT}

Line management consists of the management and operating organizations in a direct line from senior managers through the first line supervisor, person-in-charge, or team leader.

\subsection{MAINTENANCE}

Maintenance is the term applied to day-to-day activities required to sustain the ESSC in a condition such that it can be used for its designated purpose. Types of maintenance include preventive, predictive, and corrective (repair).

\subsection{PLANNED MAINTENANCE}

Planned maintenance consists of those activities that are organized, scheduled, and executed based on a pre-planned management decision process. The principle characteristic of this type of maintenance is the proactive response on the part of the organization. The need for maintenance actions is no surprise to the management team. Such actions can include outage work and preventive, predictive, and corrective maintenance assignments.

\subsection{PREDICTIVE MAINTENANCE}

Predictive maintenance activities are continuous or periodic monitoring and diagnosis activities conducted to forecast component degradation so that "as-needed" planned maintenance can be performed prior to equipment failure. This process consists of the actions necessary to monitor performance, find trends, and analyze parameter, property, and performance characteristics or signatures associated with a piece of equipment that indicate the equipment may be approaching a state in which it may no longer be capable of performing its intended function. The predictive maintenance program should be effective in reducing the failure of essential equipment by using techniques that indicate the need for additional maintenance prior to equipment failure. The data gathered should be analyzed, trends should be identified, and action needed should be defined. Action should be taken to provide feedback to the overall maintenance program in time to preclude equipment failure. The predictive maintenance program should also provide data to the preventive maintenance program. 


\subsection{PREVENTIVE MAINTENANCE}

Preventive maintenance includes periodic and planned maintenance actions taken to maintain a piece of equipment within design operating conditions and extend its life. Preventive maintenance activities are performed prior to equipment failure or to prevent equipment failure. The preventive maintenance program should define the required activities and the frequency at which they should be performed. Selection of required preventive maintenance actions should be based on manufacturer's recommendations, plant experience, and good engineering practice. The frequency of preventive maintenance should be based on adequately implementing the entire program, considering such elements as corrective/predictive maintenance results, vendor recommendations, ALARA considerations, and performance monitoring.

\subsection{RELIABILITY-CENTERED MAINTENANCE}

An integrated maintenance process that determines the most effective maintenance activity, based on an analysis of an equipment item's failure modes, failure rates, and the importance of the item to safe operation of the facility. The following five basic principles constitute the classical reliability-centered maintenance ( $\mathrm{RCM}$ ) process:

1. Focus on identifying and preserving operational systems and their functions.

2. Identify the ESSC functional failure modes and causes of operational failures.

3. Determine the work task priority that should be assigned to each failure mode.

4. As appropriate, develop or carry out the procedures in place to minimize or eliminate those failures.

5. Implement the engineered redesign requirements that may also be imposed as the result of failure modes analysis. 


\section{DISTRIBUTION}

\begin{tabular}{|c|c|c|c|}
\hline J. E. Andrews & S5-04 & B. L. Slettene & S5-14 \\
\hline J. J. Badden & T4-08 & D. P. Sparks & S5-03 \\
\hline M. P. Baka & S5-10 & E. G. Staples & R2-88 \\
\hline W. D. Bancroft & T4-08 & D. H. Steffen & R2-88 \\
\hline B. D. Biddle & S5-14 & J. E. Truax & R2-50 \\
\hline J. L. Blackwell & A2-34 & P. R. Tucker & T4-00 \\
\hline T. W. Bohan & S5-04 & J. H. Wicks, Jr. & R2-50 \\
\hline R. L. Brooks & $\mathrm{T} 4-00$ & C. M. Winkler & S5-14 \\
\hline K. A. Buchanan & $56-72$ & A. K. Yoakum & S6-71 \\
\hline R. A. Dodd & S5-07 & S. P. Youngerman & T4-01 \\
\hline K. E. Drakulich & T4-01 & F. O. Strankman & R2-50 \\
\hline T. A. Erickson & $\mathrm{T} 4-00$ & & \\
\hline J. L. Foster & S5-14 & O.S.T.I. (2) & G3-11 \\
\hline H. P. Fox & R2-88 & Doc. Proc. \& Dist. (2) & A3-89 \\
\hline P. R. Garello & S5-04 & Central Files & A3-88 \\
\hline M. S. Garrett & T4-00 & Unclass. Doc. Control & A4-65 \\
\hline J. E. Geary & S5-07 & DOE-RL Program Mana & ager \\
\hline C. J. Geier. & R2-36 & A.B. Sidpara (5) & S7-54 \\
\hline G. N. Hanson & S5-05 & & \\
\hline J. M. Hay & T4-01 & & \\
\hline R. E. Hensley & S5-06 & & \\
\hline R. M. Kelley & S5-42 & & \\
\hline D. P. Kerwick & R2-88 & & \\
\hline T. R. Law & T4-01 & & \\
\hline R. L. Legg & S5-06 & & \\
\hline M. L. Mooney & S5-06 & & \\
\hline W. L. Morris & S5-04 & & \\
\hline T. Morton & S8-05 & & \\
\hline R. J. Nicklas & R1-43 & & \\
\hline P. G. O’Connor & S5-04 & & \\
\hline A. D. Olguin & S5-08 & & \\
\hline P. L. Owen & T4-01 & & \\
\hline R. P. Raven & S5-01 & & \\
\hline T. K. Ravencraft & S5-03 & & \\
\hline D. P. Reber & T4-08 & & \\
\hline S. H. Rifaey & T4-07 & & \\
\hline W. E. Ross & S5-07 & & \\
\hline D. J. Saueressig & H6-24 & & \\
\hline C. H. Saunders & S5-06 & & \\
\hline O. M. Serrano & T4-08 & & \\
\hline L. E. Simmons & R2-54 & & \\
\hline
\end{tabular}

